\author{
Proceedings of the $9^{\text {th }}$ International Conference on Applied Informatics \\ Eger, Hungary, January 29-February 1, 2014. Vol. 2. pp. 185-193 \\ doi: 10.14794/ICAI.9.2014.2.185
}

\title{
Geovisualization of domestic nature conservation areas using $\mathrm{KML}^{*}$
}

\author{
Dániel Balla ${ }^{a}$, Marianna Zichar ${ }^{b}$ \\ ${ }^{a}$ Department of Physical Geography and Geoinformatics, University of Debrecen \\ athos04@freemail.hu \\ ${ }^{b}$ Department of Computer Graphics and Image Processing, University of Debrecen \\ zichar .marianna@inf .unideb.hu
}

\begin{abstract}
The job of geographers and geoinformatics engineers mainly focuses on data collection and analysis implying the need of digital representation of data in form of digital maps, models, etc. The range of data publishing technologies is rather wide due to the amazing development of webGIS tools as well as to the appearance of web based geographical information services. This paper demonstrates how to create digital map files for the domestic nature conservations storing also additional essential information about their main characteristics. To support the easy publication of the data, a KML file was produced where the placemarks bubbles capture the rich descriptive data from the database [2]. The structure and content customization of the KML file resulted a standard Google Earth compatible file representing the Hungarian nature conservation areas [12].
\end{abstract}

Keywords: geovisualization, nature conservation areas, KML

$M S C: 68 \mathrm{U} 35,68 \mathrm{P} 20$

\section{Introduction}

Google Earth / Map - as a world leader among the fourth generation virtual globe / web maps products - provides countless opportunities to publish our data on internet. The native file format of Google Earth is determined by the rules of Keyhole Markup Language (KML), referring to the structure of files, which can be created and saved via the user interface of the application. The usage of these files

*This research was supported by the European Union and the State of placecountryregionHungary, co-financed by the European Social Fund in the framework of TÁMOP 4.2.4. A/2-11-1-2012-0001 'National Excellence Program'. 
is not limited to only Google applications anymore, because several geographical information systems (Global Mapper, AutoCAD Map, ArcGIS, etc.) can import and export KML files.

The term geovisualization refers to a special type of visualization, which is based on geometrical data component of geospatial data. The concept relates closely to the geographical information systems (GIS), which do not only collect, systematize, visualize data about events, phenomena and objects with geospatial data but also enable to analyze these data [12]. In this paper, we demonstrate how a geospatial database about domestic nature conservation areas was built and used also for educational purposes.

\section{The characterization of KML}

A file with extension KML is actually a simple text file following the syntax rules of Keyhole Markup Language, which is an XML notation for expressing geographic annotation and visualization [11]. As a markup language its most important characteristics are:

- It is case-sensitive.

- The sequence of the elements is important.

- The descendant elements can only belong to the defined parent element.

Figure 1. shows a portion of the object oriented hierarchy of KML elements. It illustrates elements which are derived from the abstract class Feature. The placemark element can be considered the most frequently used feature, whose actual appearance is determined by its type of geometry (see Figure 2).

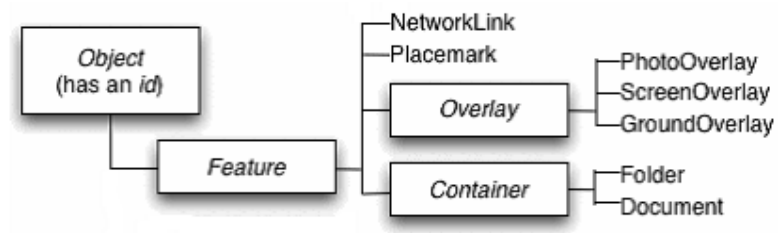

Figure 1: The abstract class Feature and its descendants [10]

The basic component of the geometrical data is the point whose coordinates must be given in the sequence of longitude, latitude, altitude where the third value is optional. We have to take care of the right sequence, because we must apply a reversed one comparing to most of GIS software. As long as a placemark contains a Point element, its coordinates will determine the geographical location of the label and icon of the placemark too. In the case of non-closing linear object, the element LineString is used; otherwise Polygon geometry has to be created. We define the polygons with outer and necessarily inner boundaries, which possess LinearRing 
geometry. The closure of LinearRing must be indicated by the coincidence of the first and last coordinate values [13].

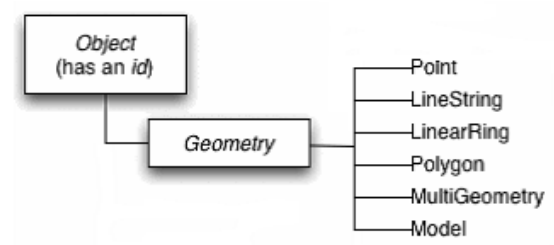

Figure 2: The descendants of abstract class Geometry [10]

MultiGeometry can be used as a container of zero or more geometry primitives belonging to the same feature. This element makes it possible to represent placecountry-regionCanada as a single feature, though it consists of several nonoverlapping polygons. If multigeometry contains also a point, then an icon can be assigned to the feature and a style map can be used to influence its visual appearance too.

We can use Model element (with some restrictions) for the visualization of an outer 3D model which is stored in COLLADA file format. The reference of the file with dae extension must be given in the Link element of Model element. The models are made separately, for example in Autodesk 3D Studio Max, Maya, and Softimage XSI or in Trimble SketchUp program. The scaling and positioning can be determined with the help of further KML elements.

The KML files usually can be compressed at a high rate, since they are basically simple text files. When saving features created by the tools of Google Earth user interface, we can select also the compressed file format (kmz). Basically, KMZ files can be created by ourselves too, if we compress the necessary files with WinZip and then we simply rename it using extension kmz. If we are aware of this knowledge, it is already easy to access the contents of a kmz file, after renaming and unpacking it. Another advantage of using the compressed files is that the virtual globes are able to visualize them directly, but we have to pay attention to providing the path correctly avoiding absolute references of additional files. The KML shares some characteristics with the GML (Geographic Markup Language) [5].

\section{Web visualization of nature conservation areas}

Internet provides novel perspectives in the field of conservation too. Web maps (no matter, whether they are static or dynamic) are now clickable and can be displayed in web browsers giving an opportunity for visualization and analysis of spatial data. Concerning the domestic conservation, we can see several examples for making data about domestic nature values available for public, but the level of data access are different. 


\subsection{The tasks of conservation}

The Act LIII. of 1996 disposes of the protection of nature in Hungary. The aim of the conservation is to reveal, handle expertly and preserve the living and non-living values of nature. Its main responsibilities are determining the range of nature values; reviewing nature values that are worth protecting, as well as reserving. There is a quite wide palette of values in nature to be protected, because not only animals and plants but microorganisms, mushrooms, minerals, springs, fossils and caves can belong to the items as well. Furthermore, quite a few man-made objects are also protected by conservation. For instance, the landscape protection, which is one subfield of nature conservation, provides the preservation of parks, arboretums or some landscapes. This is the area, where the safekeeping of cultural and natural values enwreathes mostly.

\subsection{Nature Conservation Information System}

The domestic Nature Conservation Information System (NCIS) on Figure 3. is a perfect example for applications mentioned above. Its work-up began in 2004, and one of its aims is to provide complex information for strategic planning of conservation as well as to provide base data and/or complex information for the magisterial activity [6].

The Conservation Base Object Registration System (CBRS), which is a central, object based register, forms the core of NCIS, and also provides the full integrity with the help of eight modules. Each module has a predefined set of tasks. Let us consider, for example, the Module of Protected Values; one of its tasks is to register the non-living protected values declared by the domestic and international law. Another task is to store the most important features and to create different statistics [9].

Modules of NCIS:

- Module of Biotic

- Module of Protected values

- Module of Property Registration

- Module of Trusteeship (-management)

- Module of Forestry Registration

- Module of Event diary of Land-use (handling)

- Module of Preparation for Leader decision

- Module of Public Relation

The Module of Public Relation can be used to find answers to different questions such as: What kind of protected natural values are around my residence? Where 


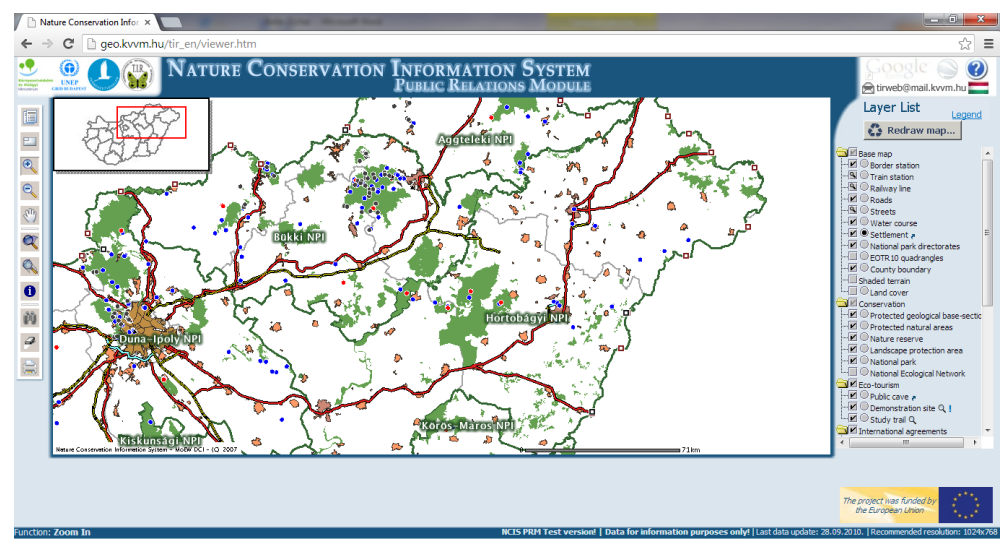

Figure 3: The interactive interface of NCIS

can I go for a nature oriented recreation or for a field trip or educational excursion? Data provided by this module serve only information purposes and do not support any other activities (for example working the geometry).

\subsection{The application $\mathrm{J} 1.2$}

The J.12 is an online application with an interactive webmap collection (Figure 4.) developed in 2012 with educational purposes and designed to support the examinations too [1]. Due to our activities the database already stores data about the significant national nature conservation areas in Hungary. Although the process of producing the necessary data will be discussed in the next section, our application belongs to the ones representing nature conservation areas. Clicking on an element in the map activates the left-hand-sided information line, where the selected item becomes highlighted and related describing data appear from the database. The students majored in Geography at the placePlaceTypeUniversity of PlaceNameDebrecen have to accomplish a test about the conservation of geoheritage in digital environment, and this interactive interface provides a convenient possibility for this. The available functions of the application depend on the user role logged in currently (Table 1.).

\begin{tabular}{|l|l|}
\hline Teacher & Student \\
\hline Upload new map data into database & Use the program for studying \\
Add/Remove an exam & Take an exam \\
Add new students & See his / her own results \\
\hline
\end{tabular}

Table 1: User roles with the available functions 


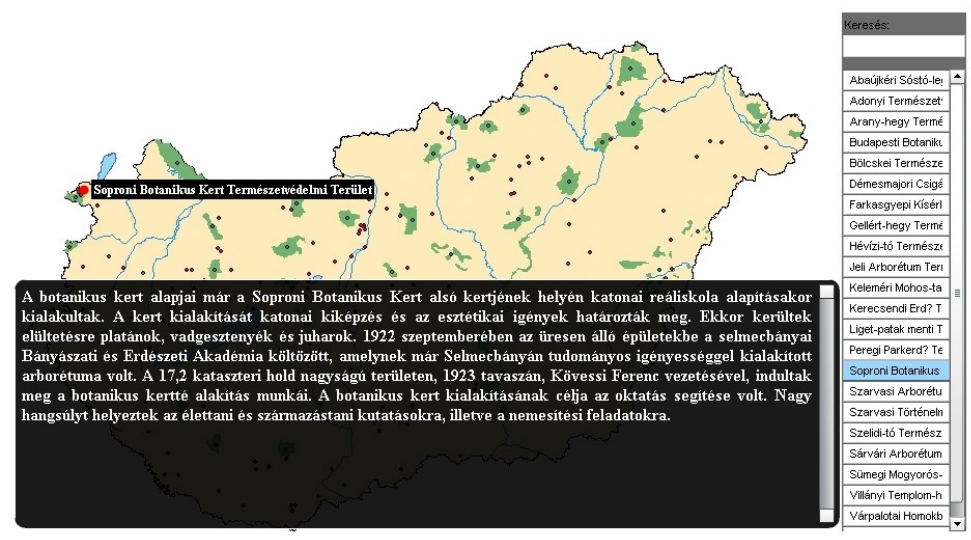

Figure 4: The e-learning interface of J.12

\section{Conservation Areas marked with placemarks}

Our objective was to build a GIS database about domestic conservation areas, which can be used for various purposes such as to create thematic maps, to work with the geometry of features, to perform analysis and also to generate KML files with customized information. This last process can support also publishing the data on internet. Concerning these application possibilities our database is more than a simple data source.

The working process started with scanning of the Conservation Map of Hungary (2009-2010) [7]. Since the map to be scanned was large, it had to be split into smaller parts. Each map was assigned the same reference system to avoid the unnecessary transformation. Although the projection transformation of the map files could have been performed with GIS software products, it was a better strategy to ensure the same reference system during the scanning [3]. It was the Unified Hungarian Projection (EOV) that was selected to perform the integrated processing. The editing and the building of base maps were performed by GIS software.

Maps with reference systems were processed with ArcGIS 9.3 ArcMap desktop software. Separate layers were created to represent the nature conservation areas, the landscape protection areas, streams, water bodies and the state border. First, the conservation areas were digitized into a shape file resulting features with point geometry. The coordinates of these points were used later to determine the geometry of placemarks representing the nature conservation areas. Additional fields were added to the attribute table, which were served as the source of the placemarks description (Figure 5).

The meaning of the additional descripting fields

- Name: Name of the nature conservation area 


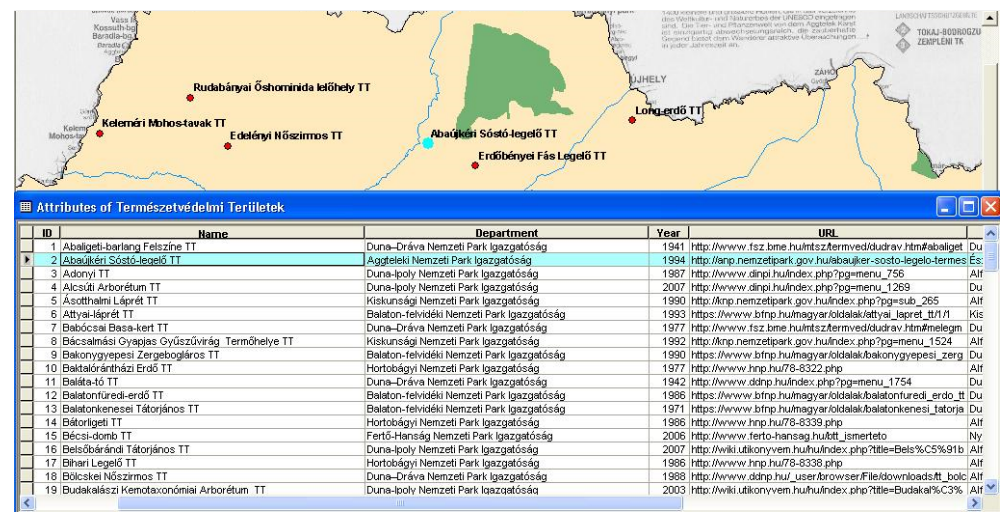

Figure 5: The attribute table of the geographical objects

- Department: Name of the official operator department of the area.

- Year: Year when the area became protected / reserved

- URL: The official website of the area

- Landscape: Exact classification of the area in the domestic landscape hierarchy

Next step was to export our data into a data file, which is recognizable by Google Earth and editable subsequently. The ArcGIS Desktop 9.3 of ESRI Company provides two tools in order to convert data to KMZ format (therefore indirectly also to the KML). The tool Layer To KML converts independent layers from ArcMap, ArcGlobe and ArcScene, whilst the Map To KML performs the conversion of more layers of a data frame. We have applied the Layer to KML tool to export data into a KMZ file. KML does not contain any element to prepare thematic maps, though it is a requirement of the user quite often. If we insist on changing the appearance of the placemarks according to an attribute values, then some solutions has to be found. One option can be the usage of different styles, when the icon, the color, the icon can be related to the thematics. Our data are visualized by symbols with different size and/or color to express the characteristics of the feature [8, 10].

In the final step we customized the content of the KML file by merging the same types of styling and by inserting some new features. The $<$ Folder $>$ element enables not only grouping of the placemarks, but touring them automatically by one single click. Nevertheless, each placemark can have an ID, which can be used as a reference in the description of the other placemarks to link one placemark to another. The placemarks descriptions in our KML files contain always two references to reach the previous and the next placemarks (Figure 6).

The element $<$ ExtendedData $>$ was selected to store the additional data about the conservation areas. Using the attributes names from the shape file (department, year, URL, landscape), the <Data name="xy" $>$ identifies the data, while 


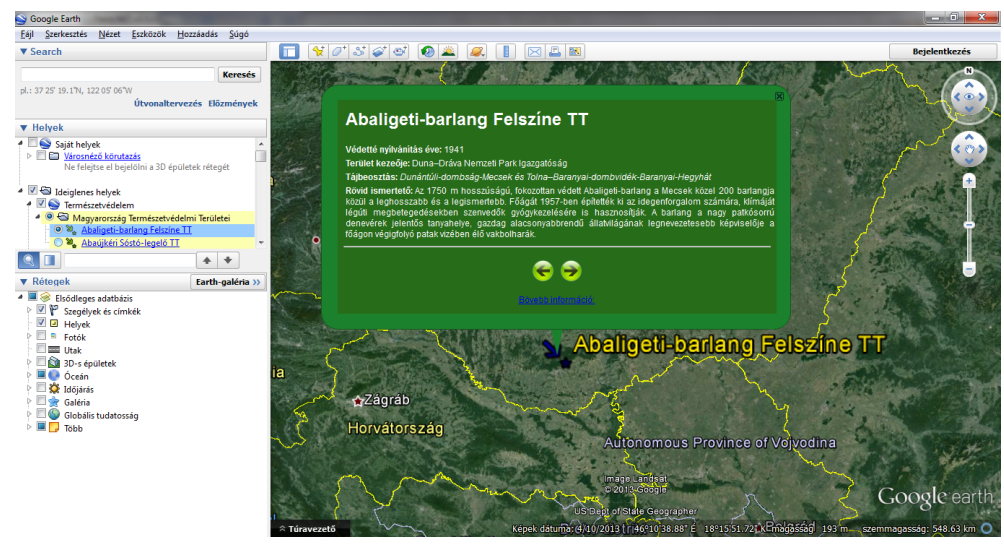

Figure 6: The appearance of a placemark with the opened bubble in Google Earth

the element $<$ value $>$ holds the value itself (Figure 7 ). The prepared KML file can be also an input of the J1.2 application extending of the range of blank maps.

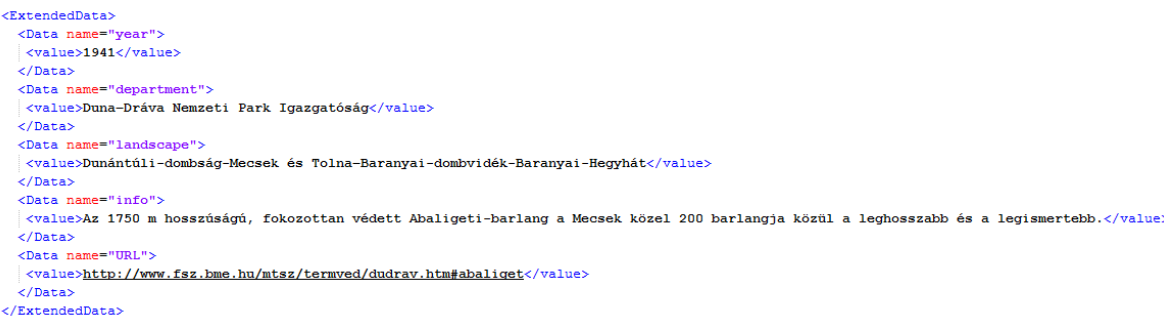

Figure 7: Usage of extended data element

\section{Conclusion}

The different applications of KML/KMZ files appear in several fields of earth sciences. Its popularity can be mainly originated from the fact that it is free and can be downloaded and used without charge. Another reason can be that its version 2.2 has become a standard. Furthermore, its compatibility with other GIS software products significantly developed compared to the past years. This paper presents the process of creating a geospatial database about the domestic conservation areas (143 items), which started with the creation of digital map files. The website of National Park Directorates as well as the home page of the Official Nature Conservation in Hungary have provided information about the concerning areas. The cadastre of small landscapes of placecountry-regionHungary was used for the 
landscape hierarchical classification [4]. The prepared spatial database has more functionality than the NCIS, and this was our objective besides demonstrating a good practice for creating shape files.

\section{References}

[1] BALLA D. Interaktív térképrejtvények tesztelése egy felsőoktatási intézményben In: Az elmélet és a gyakorlat találkozása a térinformatikában IV., Térinformatikai Konferencia és Szakkiállítás konferencia kötete, Debrecen. (2013) 71-78.

[2] BAllagh, L.M., RAuP, B. H., DUERR, R. E., KHAlSA, S. J. S., HELM, C., FOWLER, D., GUPTE, A., Representing data sets in KML: Methods and challenges, Computers and Geosciences, Vol. 37 (2011) 57-64.

[3] DETREKÔI, Á., SZABÓ, Gy.,Térinformatika, Nemzeti Tankönyvkiadó, 2003.

[4] DÖVÉNYI, Z., Magyarország kistájainak katasztere. 2. átdolgozott és bôvített kiadás, Budapest, MTA FKI, 2010.

[5] LAKE R., BURGGRAF D. S., TRNINIC M., RAE L. Geography Mark-Up Language, John Wiley \&Sons Ltd. 2004.

[6] NCIS: http://geo.kvvm.hu/tir\_en/viewer.htm

[7] Magyarország természetvédelmi térképe 2009-2010. A\$Z 1.1 Térképmúhely-Szent István Egyetem,Természetvédelmi és Ökológiai Tanszék.Baracs-Gödöllő. M:1:430000.

[8] SANDVIK B., Using KML for Thematic Mapping, Research Paper, (2008) University of Edinburgh.

[9] TAKÁCS, A. A., TAKÁCS, G., LÔRINCZ, T., A Természetvédelmi Információs Rendszer, KvVM, Budapest, 2008.

[10] WERNECKE, J., The KML Handbook, Addison-Wesley, 2009.

[11] ZICHAR, M., KML mint geovizualizációs eszköz, In Informatika a felsôoktatásban 2011 konferencia, (2011) 416-419.

[12] ZICHAR, M., Geovisualization based upon KML, Journal of Agricultural Informatics Vol 3, No 1 (2012) 19-26.

[13] ZICHAR, M., Cognitive aspects of a web-based geovisualization application, 3rd IEEE International Conference on Cognitive Infocommunications (CogInfoCom 2012), Kosice, Slovakia, (2012) 291-294. 